\title{
Comparison of Seed Treatments on the Germination of Seven Passion Fruit Species
}

\author{
Amir Rezazadeh* and Eric T. Stafne \\ Coastal Research and Extension Center, Mississippi State University, Mississippi \\ *Corresponding author
}

\begin{tabular}{|l|}
\hline Ke y w o r d s \\
$\begin{array}{l}\text { Endogenous, Exogenous, } \\
\text { Granadilla, Maypop, } \\
\text { Passiflora, Seed } \\
\text { dormancy }\end{array}$ \\
\hline Article Info \\
\hline $\begin{array}{l}\text { Accepted: } \\
\text { 26 October } 2018 \\
\text { Available Online: } \\
\text { 10 November } 2018\end{array}$ \\
\hline
\end{tabular}

\section{A B S T R A C T}

Passiflora is a large genus in the family Passifloraceae Juss. ex DC. Many Passiflora species are propagated by seed. However, seeds are often slow to germinate and have low germination rates due to seed dormancy factors. This study was conducted to evaluate four different pre-germination treatments on enhancing germination potential in seven Passiflora spp. Germination was monitored every 3 days for 90 days. Germination started after two weeks and then, a gradual increase was observed in germination in most species. Passiflora laurifolia L. showed maximal germination percentage (75\%) with scarification plus fermentation; thus, it is the recommended treatment for this species. The highest germination rate was obtained for Passiflora maliformis L. at 0.23 in scarification plus $\mathrm{GA}_{3}$. For $P$. maliformis, scarification in combination with $\mathrm{GA}_{3}$ was the most effective treatment, resulting in a germination percentage of $40 \%$. Passiflora tripartita var. Mollissima showed highest germination percentage when soaked in water or scarified plus $\mathrm{GA}_{3}(30 \%)$. Scarification alone resulted in the best germination percentage in Passiflora ligularis Juss. (30\%). No unique pre-germination treatment resulted in complete germination for all species. When compared to results from previous research, Passiflora edulis f. edulis Sims. and Passiflora incarnata L. did not germinate at acceptable levels, whereas similar germination percentages in P. tripartita var. mollisima, P. maliformis, and $P$. ligularis depended on treatment. Further research is needed to determine dormancy types present in these species and the best treatment to overcome them.

\section{Introduction}

Species within the Passifloraceae family are primarily native to regions with tropical climates. Passiflora is a large genus in the family Passifloraceae consisting of approximately 500 species, most of which are cultivated for edible fruits, pharmaceutical properties, and ornamental characteristics (Vanderplank, 1996). Most species are herbaceous, perennial vines with a rapid growth rate. Some of them like maypop $(P$. incarnata) are considered weeds due to their rampant growth (Wehtje et al., 1985).

Passiflora vines can be propagated sexually through seeds or asexually by cutting, layering, and grafting. Many Passiflora species are propagated by seed (Delanoy et al., 2006). Seeds germinate slowly and have low germination rates due to seed dormancy factors. Untreated seeds of various species 
may require two weeks to several months to germinate (Osipi and Nakagawa, 2005).

Seed dormancy is a strategy that allows seeds to avoid germination under conditions that are unfavorable for seedling establishment and plant survival (Finch-Savage and LeubnerMetzger, 2006). Seed dormancy is divided into two major categories: exogenous and endogenous. Exogenous dormancy is caused by factors outside of the seed's embryo, such as the seed coat, and it is classified into three areas: physical dormancy caused by a seed coat impermeable to oxygen and/or water, mechanical dormancy caused by a seed covering that does not allow the embryo to expand, and chemical dormancy related to inhibitors within the seed coat. Endogenous dormancy occurs due to factors in the embryo. Seeds of some species which have both exogenous and endogenous dormancy need treatments to overcome the impermeable covering first, and then for endogenous dormancy (Bewley and Black, 1994; Leadem, 1997).

In many mature, non-endospermic seeds like Passiflora spp., the embryo is mature and there is no endosperm (Ellis et al., 1985). The seeds have hard coats with a semi-permeable inner layer. They absorb water easily but contain chemical inhibitors that are difficult to leach possibly due to low permeability of the testa membrane located in seed coat (Delanoy et al., 2006). Embryos that are excised germinate rapidly, thus it appears that Passiflora spp. have exogenous dormancy which could be a combination of mechanical and chemical dormancy (Baskin et al., 2000). Dormancy can be broken by treatments including scarification, aril removal, storage for several months (Purseglove, 1979),soaking in water (McGuire 1998; Delanoy et al., 2006), various light conditions (Benvenuti et al., 2001), fire, dry heat, acid and other chemicals, hot water, mulch, cold and warm stratification, and immersing in gibberellin (Ferreira et al., 2005).However, dormancy has been reported specifically in some species, e.g.: P.mollissima (Delanoy et al., 2006) and P.edulis f. flavicarpa Deg. (Alexandre et al., 2004).

Several studies have evaluated different pregermination treatments on passion fruit species, but results are inconsistent. Establishing a protocol that ensures maximum germination requires testing several methods because each species may have different seed treatment requirements.

Understanding the dormancy characteristics that inhibit seed germination may further improve germination potential, reduce propagation costs, and facilitate cultivation of these species. The objective of this study was to find the best seed treatment to overcome dormancy for each species.

\section{Materials and Methods}

The experiment was performed in 2018 , in a greenhouse at the United States Department of Agriculture-Agricultural Research Service (USDA-ARS), Thad Cochran Southern Horticultural Laboratory in Poplarville, MS, USA (lat. 30 85'36" N, long. 8949'94'” W, elevation $97 \mathrm{~m}$, USDA hardiness zone 8b). Seeds of $P$. incarnate were obtained in 2017 from physiologically ripe fruits collected from plants grown in the same location as above. Seeds of other species including P.tripartita var. mollisima, P. maliformis, $P$. edulis f. edulis 'Frederick', P. ligularis, P.quadrangularis L., and P. laurifolia were purchased from Trade Winds Fruit (Santa Rosa, CA, USA) (Table 1).

Seeds were exposed to four pre-germination treatments as explained in Table 2. Treatments in the present study were chosen based on efforts from earlier studies (Delanoy et al., 
2006; Mendiondo and Garcia, 2009; Mabundza et al., 2010; Gurung et al., 2014). The number of seeds per treatment varied among species from 8 to 50 (Table 1). Seeds with irregular shape or color were removed after visual inspection prior to treatment.

Seeds were sowed into 72-cell seedling flats containing a commercial substrate (SunGro Sunshine Professional Mix 3, Bellevue, WA, USA). The seeds were intermittently misted at $5 \mathrm{~s}$ per $10 \mathrm{~min}$, under natural photoperiod with ambient sun light and $25 \pm 3^{\circ} \mathrm{C}$ constant daily temperature on 8th April 2018.

The day when the first seed in each treatment germinated was recorded as germination starting time $\left(\mathrm{T}_{0}\right)$. The number of germinated seeds was recorded for each treatment every 3 days for 90 days. Seeds were counted as germinated when the emerging seedling length was approximately $5 \mathrm{~mm}$. Germination percentage (GP) was calculated as follows: $\mathrm{GP}=$ (Total number of seed germinated/Total number of seeds sown in all replicates) x100. Germination rate (GR) was equal to $\Sigma^{\mathrm{n} / \Sigma(\mathrm{tn})}$, where $t$ is the time in days and $n$ is the number of seeds having completed germination on day t (Delanoy et al., 2006). Mean germination time (MGT) was calculated as MGT $=\Sigma(\mathrm{tn}) / \Sigma \mathrm{n}$ where $\mathrm{n}$ was number of seeds germinated at time $t$ and $t$ was days from sowing (Nichols and Heydecker, 1968).

The average germination percentage for each species from our study was compared to results from previous studies by taking averages of reported results for each species. Two species ( $P$. quadrangularis and $P$. laurifolia) were not compared, as reports of germination percentage were not found in the literature. In order to compare our results with those from other studies, Pearson's chi-square tests $\left(\chi^{2}\right)$ were performed in JMP 12 (SAS Institute, Cary, NC, USA) with the Distribution Procedure and the test probabilities function. $P$ values $<0.05$ were considered to be a rejection of the null hypothesis and therefore represent a deviation from the expected germination percentage.

\section{Results and Discussion}

After 90 days, the germination study was stopped for all species. Figure 1 shows germination percentages per treatment for each species. All the cumulative germination curves showed germination starting at least two weeks after sowing seeds in all treatments. Then, a gradual increase was observed in germination until it stabilized. Among the species, P. maliformis and P.edulis $\mathrm{f}$. edulis showed the earliest germination starting time $\left(\mathrm{T}_{0}\right)$ within all treatments compared to all other species (Table 3), while the latest occurred $35 \mathrm{~d}$ after sowing in scarification plus fermentation in $P$. quadrangularis and $P$. laurifolia. P. laurifolia showed maximal germination percentage (75\%) in scarification plus fermentation, but germination percentage for that treatment was lower than 50\% in all other species. Germination was observed in $P$. incarnata and $P$. quadrangularis only in response to soaking in water and scarification plus fermentation treatments (Table 3). Overall, in all species except $P$. maliformis and $P$. tripartite var. mollissima, scarification plus $\mathrm{GA}_{3}$ resulted in poor germination. Soaking in water was effective to improve germination percentage in most species. Delanoy et al., (2006) reported no effect of water on germination on three Passiflora spp., while Ellis et al., (1985) reported effectiveness of water on germination for Passiflora spp. For P. edulis f. edulis, P. ligularis, and $P$. laurifolia, the germination percentage was higher in scarified seed than non-scarified, suggesting that germination may be caused by physical seed coat restriction, at least in these three species. The highest germination rate (GR) was obtained in $P$. maliformis at 0.23 in scarification plus 
$\mathrm{GA}_{3}$, which may be due to effect of $\mathrm{GA}_{3}$ on breaking dormancy as it has been found to be effective in increasing germination in other species (Koyuncu, 2005). Scarification removes the aril, which may act as a barrier against oxygen (Obroucheva, 1999). A higher germination level was observed when arils were removed and $\mathrm{GA}_{3}$ was applied on P.alata Dryander (Ferreira et al., 2005). Delanoy et al., (2006) showed no single treatment improved germination on three species of Passiflora, which supports the results of Ellis et al., (1985) that dormancy is exogenous, and a combination of pregermination treatments may be needed to overcome both chemical and physical dormancy. In our study, soaking in water and scarification resulted in the highest germination percentages.

In a previous study (Delanoy et al., 2006), germination percentages for $P$. mollissima seeds were reported as $0 \%, 10 \%, 0 \%, 18 \%$ for control, soaking in water for $48 \mathrm{~h}$, scarification, and basal point removal plus $48 \mathrm{~h}$ $50 \mathrm{ppm} \mathrm{GA}_{3}$, respectively. These results were lower than our germination percentages for similar treatments with this species. Cárdenas et al., (2013) reported $84 \%$ germination for $P$. ligularis and $P$. edulis at 100 ppm $\mathrm{GA}_{3}$ which is higher than our results for these species with scarification plus 100 ppm $\mathrm{GA}_{3}(5 \%$ and $2 \%$, respectively).

The germination percentages for each species were compared with averaged germination percentages from other studies using chisquare test (Table 4). The larger $\chi^{2}$ is, the smaller the resulting significance becomes, and the more probable it is that differences exist between germination percentages in this study and other results. Based on previous studies (La Rosa, 1984; Delanoy et al., 2006; González-Benito et al., 2009; Beavon and Kelly, 2012; Beavon and Kelly, 2015), the average germination percentage for $P$. tripartite var. Mollissima was $42.1 \%$. Germination percentage for treatment 1 was significantly lower than the average reported, but there were no significance differences between the other treatments compared to the average. Treatment 4, soaking in distilled water for $3 \mathrm{~d}$, was the easiest and most successful method for this species. For $P$. maliformis, treatment 2resulted in significantly higher germination percentage (40\%) compared to average germination (23\%) reported for this species by Gutiérrez et $a l .$, (2011).Based on our results, it appears that pre-soaking of the seeds in water for at least $24 \mathrm{~h}$ is key to better germination success. Overall, germination percentages for this species were still $40 \%$ or less, so further studies on how to improve this are needed.

The average germination percentage for $P$. edulis from other studies was significantly higher than our results. The highest percentage in our study was $16 \%$, which is far lower than $62.79 \%$ average germination reported previously (Gutiérrez et al., 2011; Mabundza et al., 2010; Imliwabang and Alila, 2014; Ramírez Gil et al., 2015). Reasons for this are unknown; however, as Mabundza et al., (2010) noted fresh seeds germinate better and it may take much longer for germination if seeds are cleaned and stored for long periods of time. Thus, it is likely that $90 \mathrm{~d}$ was not long enough to observe seed germination for this species in this study. Germination percentages for $P$. ligularis were $5 \%, 0 \%$, and $20 \%$ for treatments 2,3 , and 4, significantly lower than the average germination (48.25\%) that was previously reported by others (Gutiérrez et al., 2011; Cárdenas et al., 2013; Aguacía et al., 2015). Only treatment 1 resulted in a similar germination percentage. This may indicate seed coat disruption via scarification or partial removal is necessary to promote viable seed germination in this species, which Gutiérrez et al., (2011) also concluded. 
Fig.1 Germination curves for seven Passiflora spp. according to treatments; (1) scarification with sandpaper (2) scarification and pre-soaking for $24 \mathrm{~h}$ in $100 \mathrm{ppm} \mathrm{GA}_{3}$ (3) scarification and fermentation for $7 \mathrm{~d}$ in $10 \%$ sucrose solution (4) pre-soaking $3 \mathrm{~d}$ in distilled water.

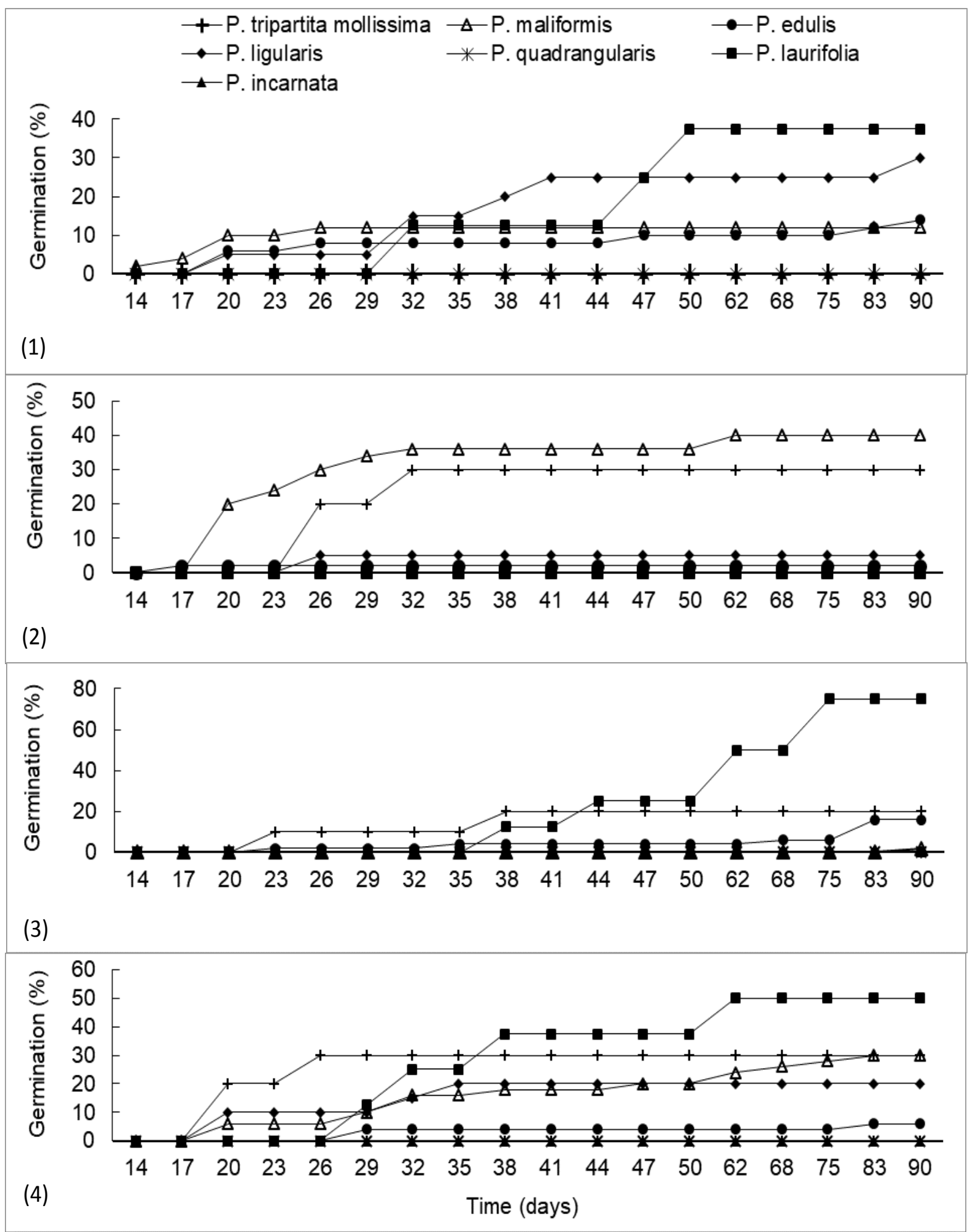


Table.1 Seven passion fruit species and number of seed per species per treatment

\begin{tabular}{|l|l|c|}
\hline Species & Common name & Number of seeds \\
\hline P. tripartitavar. mollissima & Banana Passionfruit & 10 \\
\hline P. maliformis & Sweet Calabash & 50 \\
\hline P. edulis f. edulis & 'Fredrick' Passionfruit & 50 \\
\hline P. ligularis & Sweet Granadilla & 20 \\
\hline P. quadrangularis & Giant Granadilla & 14 \\
\hline P. laurifolia & Water Lemon & 8 \\
\hline P. incarnata & Maypop & 50 \\
\hline
\end{tabular}

Table.2 Pre-germination treatments used in the seed germination test on seven passionfruit species

Table.3 The germination germination rate germination time germination

\begin{tabular}{|c|c|}
\hline Tro & ments \\
\hline 1. & Scarification with sandpaper \\
\hline 2. & Scarification and pre-soaking for $24 \mathrm{~h}$ in $100 \mathrm{ppm} \mathrm{GA_{3 }}$ \\
\hline 3. & Scarification and fermentation for $\mathbf{7 d}$ in $\mathbf{1 0 \%}$ sucrose solution \\
\hline 4. & Pre-soaking in distilled water for $\mathbf{3} \mathbf{d}$ \\
\hline
\end{tabular}

for seven passion fruit species effect of pretreatments on (GR), mean

(MGT), and starting time $\left(\mathrm{T}_{0}\right)$

\begin{tabular}{|l|} 
Species \\
\hline P. tripartitavar. mollissima \\
\hline P. maliformis \\
\hline P. edulis $\mathrm{f}$. edulis \\
\hline P. ligularis \\
\hline P. quadrangularis \\
\hline P. laurifolia \\
\hline P. incarnata \\
\hline Average
\end{tabular}

\begin{tabular}{|c|c|c|c|c|c|c|c|c|c|c|c|}
\hline \multicolumn{4}{|c|}{ GR } & \multicolumn{4}{c|}{ MGT (d) } & \multicolumn{3}{c|}{ T $_{\mathbf{0}}(\mathbf{d})$} \\
\hline $1^{\mathrm{a}}$ & 2 & 3 & 4 & 1 & 2 & 3 & 4 & 1 & 2 & 3 & 4 \\
\hline 0.00 & 0.03 & 0.02 & 0.03 & 0 & 53 & 54 & 49 & 0 & 23 & 19 & 17 \\
\hline 0.07 & 0.23 & 0.01 & 0.17 & 47 & 50 & 89 & 56 & 15 & 16 & 89 & 15 \\
\hline 0.08 & 0.01 & 0.09 & 0.03 & 52 & 46 & 64 & 56 & 19 & 15 & 15 & 17 \\
\hline 0.07 & 0.01 & 0.00 & 0.05 & 56 & 51 & 0 & 51 & 19 & 26 & 0 & 20 \\
\hline 0.00 & 0.00 & 0.02 & 0.00 & 0 & 0 & 64 & 0 & 0 & 0 & 35 & 0 \\
\hline 0.03 & 0.00 & 0.07 & 0.05 & 63 & 0 & 69 & 58 & 32 & 0 & 35 & 26 \\
\hline 0.00 & 0.00 & 0.00 & 0.05 & 0 & 0 & 0 & 46 & 0 & 0 & 0 & 13 \\
\hline 0.04 & 0.04 & 0.03 & 0.05 & 31 & 29 & 49 & 45 & 12 & 11 & 28 & 15 \\
\hline
\end{tabular}

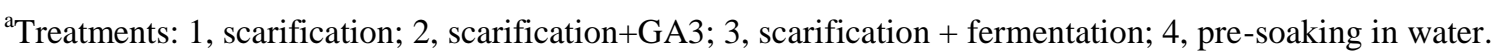


Table.4 Germination percentage of seven passion fruit species and four seed treatments with their distributional goodness-of-fit when compared to results from other studies

\begin{tabular}{|c|c|c|c|c|}
\hline Species & Treatment & GP (\%) & $x^{2 z}$ & $P$ \\
\hline \multirow[t]{4}{*}{ P. tripartita var.mollissima } & 1 & 0 & 7.2712 & $0.0070^{y}$ \\
\hline & 2 & 30 & 0.5411 & 0.4420 \\
\hline & 3 & 20 & 1.9869 & 0.1587 \\
\hline & 4 & 30 & 0.5911 & 0.4420 \\
\hline \multirow[t]{4}{*}{ P. maliformis } & 1 & 12 & 3.4161 & 0.0646 \\
\hline & 2 & 40 & 8.1592 & 0.0043 \\
\hline & 3 & 2 & 12.4506 & 0.0004 \\
\hline & 4 & 30 & 1.3834 & 0.2395 \\
\hline \multirow[t]{4}{*}{ P. edulis f. edulis } & 1 & 14 & 50.7051 & $<0.0001$ \\
\hline & 2 & 2 & 78.7718 & $<0.0001$ \\
\hline & 3 & 16 & 46.6259 & $<0.0001$ \\
\hline & 4 & 6 & 68.7321 & $<0.0001$ \\
\hline \multirow[t]{4}{*}{ P. ligularis } & 1 & 30 & 2.6678 & 0.1024 \\
\hline & 2 & 5 & 14.9829 & $<0.0001$ \\
\hline & 3 & 0 & 18.6473 & $<0.0001$ \\
\hline & 4 & 20 & 6.3923 & 0.0115 \\
\hline \multirow[t]{4}{*}{ P. quadrangularis } & 1 & 0 & $N^{x}$ & NA \\
\hline & 2 & 0 & NA & NA \\
\hline & 3 & 14 & NA & NA \\
\hline & 4 & 0 & NA & NA \\
\hline \multirow[t]{4}{*}{ P. laurifolia } & 1 & 38 & NA & NA \\
\hline & 2 & 0 & NA & NA \\
\hline & 3 & 75 & NA & NA \\
\hline & 4 & 50 & NA & NA \\
\hline \multirow[t]{4}{*}{ P. incarnata } & 1 & 0 & 30.6452 & $<0.0001$ \\
\hline & 2 & 0 & 30.6452 & $<0.0001$ \\
\hline & 3 & 0 & 30.6452 & $<0.0001$ \\
\hline & 4 & 8 & 19.1002 & $<0.0001$ \\
\hline
\end{tabular}

Pearson's chi-square test $\left(\chi^{2}\right)$ test.

${ }^{\mathrm{y}} P$ values $<0.05$ are significant and are a rejection of the null hypothesis that the observed distributions are the same as expected distributions.

${ }^{\mathrm{x}}$ Not enough data available to make comparisons. 
The highest germination percentage for $P$. incarnate was $8 \%$ in treatment 4 , which was significantly lower than the average germination of $38.2 \%$ reported by Wehtje et al., (1985) and Benvenuti et al., (2001). Both authors reported that $P$. incarnata seed germination can be inhibited by light and that pre-soaking of seeds is necessary for even moderate levels of germination.

The greenhouse temperature that the seeds were kept in our study was around $25^{\circ} \mathrm{C}$. Benvenuti et al., (2001) found that higher temperatures of $35^{\circ} \mathrm{C}$ along with the absence of light were the best conditions for germination of $P$. incarnata. Even under the optimized conditions, complete germination was not achieved in their study. More effort in understanding seed dormancy factors in this species is needed.

Based on our results, scarification plus fermentation is the recommended treatment for $P$. laurifolia seeds, resulting in $75 \%$ germination. For $P$. maliformis, scarification in combination with $\mathrm{GA}_{3}$ was the most effective treatment on germination percentage (40\%). P. tripartite var. mollissima showed highest germination percentage when soaked in water or scarified plus $\mathrm{GA}_{3}(30 \%)$. Scarification alone resulted in best germination percentage in P. ligularis $(30 \%)$. Germination percentage was highest $(20 \%)$ for $P$. incarnata when pre-soaked in water. Scarification plus fermentation is suggested as a treatment to improve germination in $P$. edulis. Results indicate that the seed pregermination treatments of the seven species tested in this study may improve germination potential; however, it depended highly on species. No pre-germination treatment resulted in complete germination for all species. Dormancy is probably exogenous and combination of chemical and mechanical based on the results obtained. Further research is needed to determine dormancy types present in these species and the individual best treatments to overcome them.

\section{Acknowledgements}

The project was founded through a Specific Cooperative Agreement between Mississippi State University and USDA-ARS, supported by the Mississippi Agricultural, Forestry and Experiment Station and Mississippi State University Extension Service. This material is based upon work that is supported by the National Institute of Food and Agriculture, U.S. Department of Agriculture, Hatch project under accession number 0232036.

\section{References}

Aguacía, L.M., Miranda, D., and Carranza, C. 2015. Effect of fruit maturity stage and fermentation period on the germination of passion fruit (Passiflora edulis $\mathrm{f}$. flavicarpa Deg.) and sweet granadilla seeds (Passiflora ligularis Juss.). Agron.Colombiana. 33: 305-314. Alexandre, R.S., Júnior, A.W., da Silva Negreiros, J.R., Parizzotto, A., and Bruckner, C.H. 2004. Germinação de sementes de genótipos de maracujazeiro. Pesquisa Agropecuária Brasileira. 39:1239-1245.

Alila, P. 2014. Germination studies on passionfruit cultivars with different presowing seed treatments. Acta Hort. 1178: 41-46.

Baskin, J.M., Baskin, C., and Xiaojie, L. 2000. Taxonomy, anatomy and evolution of physical dormancy in seeds. Plant Spec. Biol. 15:139-153.

Beavon, M.A., and Kelly D. 2012. Invasional meltdown: pollination of the invasive liana Passiflora tripartita var. mollissima (Passifloraceae) in New Zealand. N.Z. J. Ecol.36: 100-107.

Beavon, M.A., and Kelly D. 2015. Dispersal of banana passion fruit (Passiflora 
tripartita var. mollissima) by exotic mammals in New Zealand facilitates plant invasiveness. N.Z. J. Ecol. 39: 4349.

Benvenuti, S., Simonelli, G., and Macchia, M. 2001. Elevated temperature and darkness improve germination in Passiflora incarnata L. seed. Seed Sci. Technol. 29:533-541.

Bewley, J.D., and Black M. 1994. Seeds Physiology of Development and Germination. Plenum Press, New York, NY. $451 \mathrm{pp}$.

Cárdenas, J., Carlos, C., Diego, M., and Stanislav, M.2013. Effect of $\mathrm{GA}_{3}$, $\mathrm{KNO} 3$, and removing of basal point of seeds on germination of sweet granadilla (Passiflora ligularis Juss) and yellow passion fruit (Passiflora edulis f. flavicarpa). Rev. Brasil. Frutic. 35:853-859.

Delanoy, M., Van Damme, P., Scheldeman, X., and Beltran, J. 2006. Germination of Passiflora mollissima (Kunth) L.H. Bailey, Passiflora tricuspis Mast. and Passiflora nov sp. seeds. Sci. Hortic. 110:198-203.

Ellis, R.H., Hong, T.D., and Roberts, E.H. 1985. Handbook of seed technology for genebanks, Vol. II: Compendium of specific germination. Information and test recommendations. Intl. Board Plant Genet. Resources, (IBPGR), Rome.

Ferreira, G., De Oliveira, A., Rodrigues, J.D., Bravo Dias, G., Detoni, A.M., and Tesser, S.M. 2005. Effect of the aril on germination of seeds of Passiflora alata Curtis in different substrates and submitted to treatments with gibberellin. Rev. Bras. Frutic. 27:277280.

Finch-Savage, W.E., and Leubner-Metzger, G. 2006. Seed dormancy and the control of germination. New Phytol. 1716:501523.
González-Benito, M.E., Aguilar, N., and Ávila, T. 2009. Germination and embryo rescue from Passiflora species seeds post-cryopreservation. CryoLetters. 30: 142-147.

Gurung, N., Swamy, G.S.K., Sarkar, S.K., and Ubale, N.B. 2014. Effect of chemicals and growth regulators on germination, vigour and growth of passion fruit (Passiflora edulis Sims.). The Bioscan. 9:155-157.

Gutiérrez, M.I., Miranda, D., and CárdenasHernández, J.F. 2011. Effect of pregermination treatments on the germination of seeds of purple passion fruit (Passiflora edulis Sims.), sweet granadilla (Passiflora ligularis Juss.) and cholupa (Passiflora maliformis L.). Revista Colombiana de Ciencias Hortícolas. 5: 209-219.

Koyuncu, F. 2005. Breaking seed dormancy in black mulberry (Morusnigra L.) by cold stratification and exogenous application of gibberellic acid. Acta Biol. Crac. Ser. Bot. 47:23-26.

La Rosa, A.M. 1984. The biology and ecology of Passiflora mollissima in Hawaii. Univ. Hawaii-Manoa, Dept. Bot., Tech. Rpt. 50. Coop. Natl. Park Studies Unit, Honolulu, Hawaii.

Leadem, C.L. 1997. Dormancy-unlocking seed secrets. Pages. 43-52 inT.D. Landis and J.R. Thompson, eds. Natl. Proc., Forest Conser. Nursery Assn. Gen. Tech. Rep. PNW-GTR-419. U.S. Dept. of Agr., Forest Serv., Pacific Northwest Res. Sta., Portland, OR.

Mabundza, R.M., Wahome, P., and Masarirambi, M. 2010. Effects of different pre-germination treatment methods on the germination of passion (Passiflora edulis) seeds. J. Agr. Soc. Sci. 6:57-60.

McGuire, C.M. 1998. Field performance and phenotypic variation of Passiflora 
incarnata L. in New York State. Hort Science 33:240-241.

Mendiondo, G.M., and Amela Garcia, M.T. 2009. Germination of stored and scarified seeds of Passiflora caerulea L. (Passifloraceae). Plant Biosyst. 143:369-376.

Nichols, M.A., and Heydecker, W. 1968. Two approaches to the study of germination data. Proc. Intl. Seed Testing Assn. 33:531-540.

Obroucheva, N.V. 1999. Seed Germination: A Guide to the Early Stages. Backhuys Publishers, Leiden, Netherlands. 158 pp.

Osipi, E.A.F., and Nakagawa, J. 2005. Effect of temperature on evaluation of physiological quality of seeds on sweet passion-fruit (Passiflora alata Dryander). Rev. Bras. Frutic. 27: 179181.
Purseglove, J.W. 1979. Tropical Crops: Dicotyledons. 5end ed. Longman, London. 719 pp.

Ramírez Gil, J.G., Muñoz Agudelo, M., Osorno Bedoya, L., Osorio, N.W., and Morales Osorio, J.G. 2015. Germination and growth of purple passion fruit seedlings under pre-germination treatments and mycorrhizal inoculation. Pesquisa Agropecuaria Trop. 45: 257265.

Vanderplank, J. 1996. Passion Flowers and Passion Fruit. 2end ed. MIT Press. Cambridge, MA.176 pp.

Wehtje, G., Reed, R.B., and Dute, R.R. 1985. Reproductive biology and herbicidal sensitivity of maypop passionflower (Passiflora incarnata). Weed Sci. 33:484-490.

\section{How to cite this article:}

Amir Rezazadeh and Eric T. Stafne. 2018. Comparison of Seed Treatments on the Germination of Seven Passion Fruit Species. Int.J.Curr.Microbiol.App.Sci. 7(11): 3074-3083. doi: https://doi.org/10.20546/ijcmas.2018.711.353 